\title{
Sensitivity to wheat, gluten and FODMAPs in IBS: facts or fiction?
}

\author{
Roberto De Giorgio, ${ }^{1}$ Umberto Volta, ${ }^{1}$ Peter R Gibson ${ }^{2}$
}

${ }^{1}$ Department of Medical and Surgical Sciences, Centro di Ricerca Bio-Medica Applicata (C.R.B.A.) and Digestive System, St. Orsola-Malpighi Hospital, University of Bologna, Bologna, Italy

${ }^{2}$ Department of Gastroenterology Alfred Hospital, Monash University, Melbourne, Australia

\section{Correspondence to} Professor Peter Gibson, Department of Gastroenterology, Alfred Hospital, 99 Commercial Road, Melbourne Victoria 3004 , Australia; peter.gibson@monash.edu

Received 13 April 2015 Revised 12 May 2015 Accepted 29 May 2015 Published Online First 15 June 2015
CrossMark

\footnotetext{
To cite: De Giorgio R, Volta U, Gibson PR. Gut 2016;65:169-178.
}

\section{ABSTRACT}

IBS is one of the most common types of functional bowel disorder. Increasing attention has been paid to the causative role of food in IBS. Food ingestion precipitates or exacerbates symptoms, such as abdominal pain and bloating in patients with IBS through different hypothesised mechanisms including immune and mast cell activation, mechanoreceptor stimulation and chemosensory activation. Wheat is regarded as one of the most relevant IBS triggers, although which component(s) of this cereal is/are involved remain(s) unknown. Gluten, other wheat proteins, for example, amylase-trypsin inhibitors, and fructans (the latter belonging to fermentable oligo-di-mono-saccharides and polyols (FODMAPs)), have been identified as possible factors for symptom generation/exacerbation. This uncertainty on the true culprit(s) opened a scenario of semantic definitions favoured by the discordant results of double-blind placebo-controlled trials, which have generated various terms ranging from non-coeliac gluten sensitivity to the broader one of non-coeliac wheat or wheat protein sensitivity or, even, FODMAP sensitivity. The role of FODMAPs in eliciting the clinical picture of IBS goes further since these short-chain carbohydrates are found in many other dietary components, including vegetables and fruits. In this review, we assessed current literature in order to unravel whether gluten/wheat/FODMAP sensitivity represent 'facts' and not 'fiction' in IBS symptoms. This knowledge is expected to promote standardisation in dietary strategies (gluten/wheat-free and low FODMAP) as effective measures for the management of IBS symptoms.

\section{INTRODUCTION}

IBS can be considered the prototype of all functional bowel disorders for its high prevalence worldwide and impact on patients' quality of life. ${ }^{1}{ }^{2}$ Patients with IBS suffer from abdominal pain or discomfort associated with bowel habit changes. In the absence of established biomarkers, for which research is actively ongoing, the diagnosis relies upon symptom evaluation according to the well-known Rome III criteria, which are currently the benchmark for IBS identification. ${ }^{1}{ }^{2}$ Current estimates indicate that IBS prevalence ranges from $10 \%$ to $25 \%$ in the general population with a typical predominance of young adult women (3:1 F:M ratio). ${ }^{3-6}$ Usually regarded as a harmless disorder, IBS is known to severely hamper the patient's quality of life at least as much as organic disorders and is responsible for repeated absence from work as well as suboptimal performance on the workplace with relevant social costs.

The mechanisms leading to symptom generation in IBS remain highly debated, although growing

\section{Key messages}

- Dietary factors are known to precipitate/ exacerbate IBS symptoms, for example, abdominal pain, bloating and bowel habit changes.

- Gluten, wheat and related proteins (eg, amylase-trypsin inhibitors, and fermentable oligo-di-mono-saccharides and polyols (FODMAPs) are the most relevant IBS symptom triggers, although the true 'culprit(s)' is/are still not well established;

- Double-blind placebo-controlled with cross-over trials represent the current gold standard for confirming the dietary factor(s) involved in functional symptom generation.

- Based on the different dietary factors responsible for symptom generation, patients can be labelled non-coeliac gluten sensitive or more broadly non-coeliac wheat or wheat protein sensitivity or, even, FODMAP sensitive.

- A better understanding of gluten/wheat/ FODMAP sensitivity can be translated into new effective dietary strategies for the management of patients with IBS.

knowledge indicates that multiple factors are involved. Altered brain-gut axis with gut dysmotility and hypersensitivity, immune activation, leaky gut barrier function, changes in gut microbiome, genetic factors, infections, as well as psychological/ psychiatric factors, can all contribute to symptom generation. ${ }^{578}$ The interest of the scientific community for these mechanisms has somehow obscured one of the most logical pathogenic factors - the role of food in triggering and perpetuating IBS symptoms. Recently, however, a number of studies linking type of food consumption to functional symptoms refuelled the interest in dietary factors in IBS, thus opening new avenues to treatment strategies. ${ }^{9}$ This review aims first to briefly address some key mechanisms involved in food-related symptom genesis; and second, to address the ongoing controversy about wheat, gluten and fermentable oligo-di-mono-saccharides and polyols (FODMAPs) in IBS, a controversy that is generating much debate and a growing body of research that is slowly sorting fact from fiction.

\section{MECHANISMS BY WHICH FOOD MIGHT INDUCE SYMPTOMS}

Common clinical experience indicates that food ingestion precipitates or exacerbates symptoms, 
such as abdominal pain and bloating, in about $60 \%$ of patients with IBS. The onset or worsening of symptoms can occur rapidly after meal ingestion, namely, within $15 \mathrm{~min}$ in $28 \%$, up to $3 \mathrm{~h}$ in $93 \%$ of patients with IBS. ${ }^{10}$ Foods can trigger symptoms in IBS via several possible mechanisms, which include immune and mast cell activation, mechanoreceptor activation via luminal distension associated with visceral hypersensitivity and altered motility, and chemosensory activation by bioactive molecule activity ('food chemicals') (figure 1). ${ }^{11}$

\section{Immune and mast cell activation}

Low-grade inflammation (mainly characterised by a dense mast cell infiltrate) is present in colonic mucosal biopsies of about two-thirds of patients with IBS. ${ }^{12}$ Mast cells are known to release a variety of mediators, including serine proteases, which evoke neuronal hyperexcitability, a major factor for functional symptom generation (eg, pain). ${ }^{13}{ }^{14}$ Food components, particularly proteins, may be pathogenically involved with this process, either primarily or secondarily. One possible interpretation of such mucosal changes is that food components/antigens pass through a leaky (ie, more permeable) epithelial barrier, leading to mast cell infiltration and activation, thereby leading to IBS symptoms. ${ }^{5}$ Mast cells can be activated by allergy-like mechanisms, such as those involving food-specific immunoglobulin $\mathrm{E}$ (IgE). However, tests for food allergy detection that use the systemic immune compartment, such as skin-prick tests, have a poor sensitivity and specificity. ${ }^{15}$ Thus, immune response to food in IBS may require more sophisticated approaches to be demonstrated.

One method is to present the offending protein to the gut immune compartment. A sort of 'mucosal prick test' renamed as colonoscopic allergen provocation (COLAP) test involves colonoscopy-guided submucosal injection to unravel food hypersensitivity. ${ }^{16}$ Seventy-seven per cent of a population with gut symptoms thought possibly related to food hypersensitivity had a positive COLAP test, which was consistently negative in the few control subjects. A more refined technique (confocal laser endomicroscopy) demonstrated that submucosal injection of food antigens caused increased infiltration with intraepithelial lymphocytes (IEL), formation of epithelial leaks/gaps and widening of intervillous spaces in more than half of IBS, and not in a small group of controls. ${ }^{17}$ These changes occurred within a few minutes of food antigen injection and predicted the clinical response to specific food withdrawal. Alternatively, circulating basophils have been used to determine allergens in vitro without the need to risk an allergic reaction when the patient is challenged. Indeed, basophil activation when exposed in vitro to dietary proteins, especially of wheat and milk origin, correlated with clinical responsiveness to dietary restriction of the relevant protein by one group, ${ }^{18}$ but another could find no specificity for basophil activation. ${ }^{19}$ Overall, these studies do suggest that reaction to food, whether it be via allergic, other immune or epithelial-damaging mechanisms, may play a role in the genesis of symptoms in some patients presenting with IBS. Confirmatory studies are needed before reaching diagnostic relevance.

\section{Mechanoreceptor activation}

Many different foods can evoke intestinal (luminal) distension, which, in the presence of visceral hypersensitivity and abnormal gut motility, may trigger bloating, abdominal pain and changes in bowel habit. Dietary FODMAPs are believed to act via luminal distension as discussed later. ${ }^{20-22}$

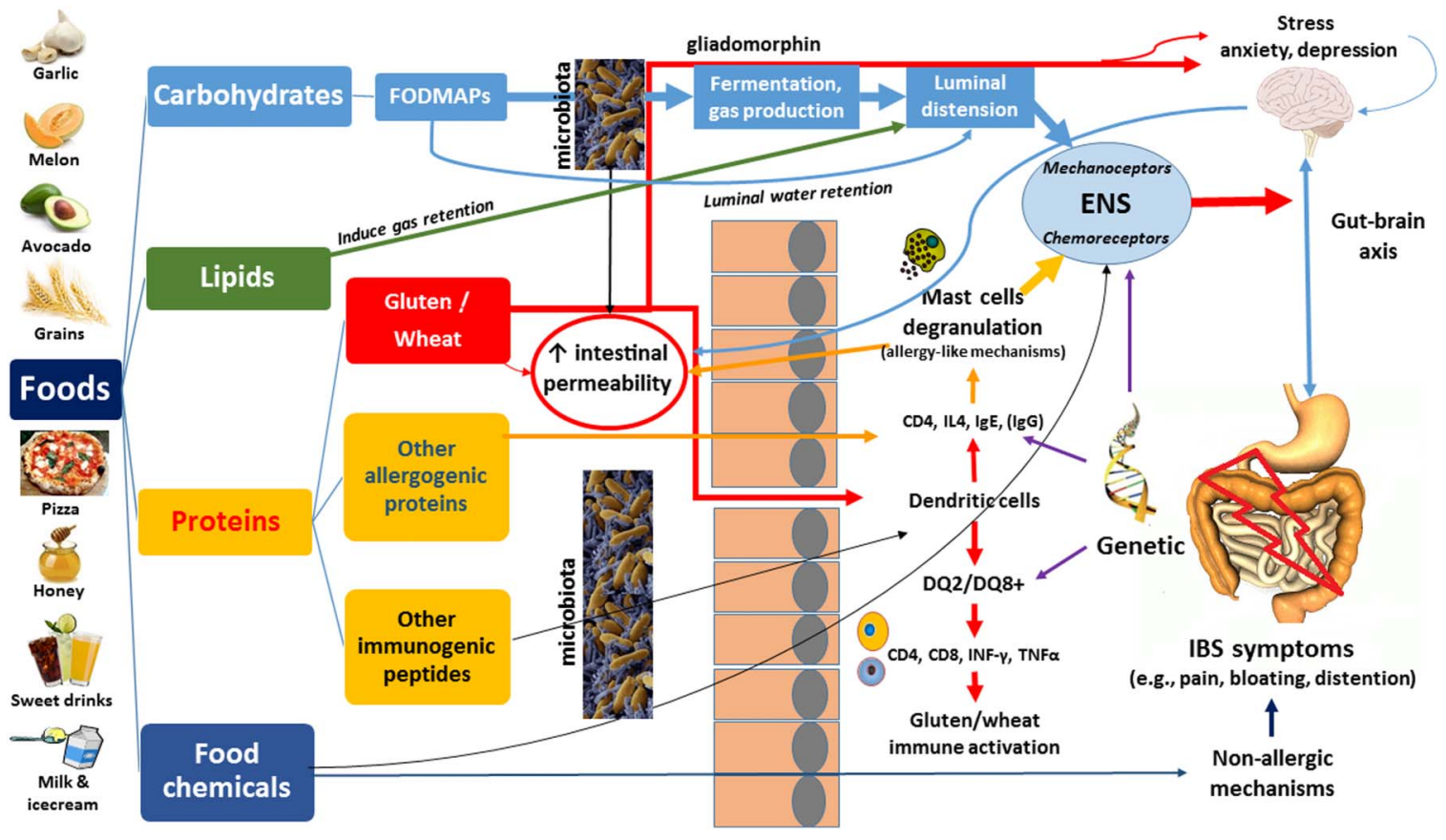

Figure 1 Synopsis illustrating the interplay among several dietary factors, such as gluten, wheat and fermentable oligo-di-mono-saccharides and polyols (FODMAPs), that contribute to generate a wide array of symptoms in patients with IBS. For example, in the gut lumen, the interaction between dietary factors (carbohydrates, lipids and proteins) and the microbiota results in gas production and/or passage of noxious macromolecules triggering the release of mast cell mediators and the activation of the immune system. These mechanisms are at the base of mechanoreceptor and sensory nerve pathway activation ultimately responsible for commonly reported symptoms, such as abdominal pain, bloating and distension, especially in genetically predisposed patients. Moreover, stress or gliadomorphin evoked anxiety/depression, can directly impair intestinal barrier function, thus favouring passage of previously mentioned noxious macromolecules. ENS, enteric nervous system; IgE, immunoglobulin $\mathrm{E}_{\text {; }} \operatorname{lgG}$, immunoglobulin G; IL4, interleukin-4; INF- $\gamma$, interferon- $\gamma$; TNF $\alpha$, tumour necrosis factor $\alpha$. 


\section{Chemosensory activation by bioactive molecules}

A wide array of foods contains potentially bioactive chemicals, such as salicylates, amines, benzoates and glutamate, which can elicit neurally and/or mast cell-mediated mechanisms contributing to IBS symptoms. ${ }^{11} 23{ }^{24}$ However, a specific cause-effect mechanism between bioactive chemicals and symptoms is still far from being established. Empirical clinical experience indicates an improvement of IBS symptoms as a result of reduction of the dietary intake of bioactive chemicals. Nonetheless, clinicians should have a cautionary approach before advising dietary restrictions as nutritional defects may became a serious issue for the patient.

\section{WHEAT SENSITIVITY}

Wheat is considered one of the foods known to evoke IBS symptoms. ${ }^{25}$ However, which component(s) of wheat is/are actually responsible for these clinical effects still remain(s) an unsettled issue. ${ }^{26}$ The two parts of wheat that are thought to have a mechanistic effect comprise proteins (primarily, but not exclusively, gluten) and carbohydrates (primarily indigestible short-chain components, FODMAPs). Two distinct views characterise the clinical debate: one line identifies wheat proteins as a precipitating/perpetuating factor leading to symptoms, while the other believes that FODMAPs are the major trigger for IBS.

\section{The controversy over nomenclature}

If gluten is a major trigger for IBS, it expands the gluten-related disorders by adding a new entity now referred to as non-coeliac gluten sensitivity (NCGS). ${ }^{27}$ Indeed, coeliac disease-like abnormalities were reported in a subgroup of patients with IBS many years ago. ${ }^{28} \mathrm{~A}$ recent expert group of researchers reached unanimous consensus attesting the existence of a syndrome triggered by gluten ingestion. ${ }^{29}$ This syndrome recognises a wide spectrum of symptoms and manifestations including an IBS-like phenotype, along with an extra-intestinal phenotype, that is, malaise, fatigue, headache, numbness, mental confusion ('brain fog'), anxiety, sleep abnormalities, fibromyalgia-like symptoms and skin rash. In addition, other possible clinical features include gastro-oesophageal reflux disease, aphthous stomatitis, anaemia, depression, asthma and rhinitis. Symptoms or other manifestations occur shortly after gluten consumption and disappear or recur in a few hours (or days) after gluten withdrawal or challenge. A fundamental prerequisite for suspecting NCGS is to rule out all the established gluten/wheat disorders, comprising coeliac disease (CD), gluten ataxia, dermatitis herpetiformis and wheat allergy. The major issue not addressed by the consensus opinion was that gluten is only one protein contained within wheat. Other proteins, such as amylase-trypsin inhibitors (ATIs), ${ }^{30}$ are strong activators of innate immune responses in monocytes, macrophages and dendritic cells. Furthermore, wheat germ agglutinin, which has epithelial-damaging and immune effects at very low doses at least in vitro, might also contribute to both intestinal and extraintestinal manifestations of NCGS. ${ }^{31}$

Consequently, a further development of this research field led to suggestions of a broader term, non-coeliac wheat sensitivity (NCWS). The problems with this term are twofold. First, rye and barley may be inappropriately excluded. Second, the term will refer to any wheat component that might be causally related to induction of symptoms and, therefore, will also include fructans (FODMAPs). It will then have a very nonspecific connotation in IBS. A more correct term would then be non-coeliac wheat protein sensitivity (NCWPS) since this does not attribute effects to gluten without evidence of such specificity, eliminates the issue of fructan-induced symptoms and avoids the unknown contribution of rye and barley proteins to the symptoms. Both NCGS, the currently accepted term, and NCWPS will be used subsequently in this paper.

\section{Evidence for involvement of sensitivity to wheat proteins in IBS}

Due to the lack of biomarkers, the diagnosis of NCGS still challenges clinicians as it remains based only on clinical criteria. 3233 In addition, one of the major diagnostic criteria for NCGS, which is the improvement of symptoms after wheat protein/ gluten exclusion, might be influenced by a placebo effect experienced by patients after food elimination from their usual diet. ${ }^{34}$ This is compounded by a huge media drive, via publications, printed media, television and the internet supported strongly by celebrity endorsement where a gluten-free diet (GFD) has been embraced not only as a solution to many symptoms but also with the erroneous belief that it is healthy not to eat gluten and, even more, that GFD helps to lose weight. As a result, a high proportion of US population, for example, switched to GFD with a marked increase of the global sale of gluten-free foods. ${ }^{35}$ Because of these facts, it has been hypothesised that NCGS might be a false problem created by media rather than an emerging clinical entity. ${ }^{36}$ However, recent studies have provided strong signals that wheat protein/gluten may specifically induce GI and extraintestinal, including psychological, symptoms in at least some patients with NCGS. ${ }^{37-39}$

Although epidemiological data are still scanty and approximate, NCGS may be at least as common as CD (ie, occurring in $\geq 1 \%$ of the general population). ${ }^{40}$ Similarly to IBS, NCGS affects more young (third decade of life) women (F:M ratio $>3: 1$ ), while, in contrast to IBS, NCGS is diagnosed more commonly in tertiary than primary care centres. According to the National Health and Nutrition Examination Survey, a primary care programme, NCGS was found in $0.6 \%$ over 7762 subjects, ${ }^{41}$ whereas at the Celiac Disease Center (University of Maryland) 6\% over 5896 subjects were identified as NCGS. ${ }^{42}$ In an Italian multicentre prospective survey carried out on 38 referral paediatric and adult centres for the diagnosis of glutenrelated disorders, NCGS and CD were respectively diagnosed in $391(3.2 \%)$ and $340(2.8 \%)$ over 12255 patients consecutively studied in a 1-year period. ${ }^{40}$ Such data have to be viewed, however, in the light of the failure to actually prove specific sensitivity to gluten/wheat proteins in double-blind placebocontrolled (DBPC) cross-over studies in most patients fulfilling the criteria for NCGS. ${ }^{39} 43$

Although still a matter of debate, several factors have been postulated to play a role in NCGS pathogenesis. First, NCGS may be an immune-mediated disorder evoked by innate immunity, as highlighted by the increased expression of toll-likereceptors (TLRs), mainly TLR2, in the intestinal mucosa. ${ }^{44}$ More recently, however, the evidence of an increased level of interferon- $\gamma$ in small intestinal biopsies of patients with NCGS after a short (3-day) gluten challenge lends support to a possible role exerted by adaptive immunity in this syndrome. ${ }^{45}$ In line with the latter findings, the detection of antigliadin antibodies in $>50 \%$ of patients with NCGS provides further support to adaptive immunity in NCGS pathogenesis. ${ }^{46}$ Second, discordant data exist on epithelial barrier dysfunction. Initial studies showed a reduced intestinal permeability in NCGS, thus suggesting an increased intestinal barrier function. This finding has been also supported by a significantly higher expression of claudin-4 mRNA, a marker of reduced permeability, in duodenal 
biopsies of patients with NCGS. ${ }^{44}$ However, more recently, some evidence for increased intestinal permeability in a subgroup of patients with IBS-D carrying the human leucocyte antigen (HLA)-DQ2+/DQ8 + was reported when consuming a gluten-containing diet compared with a GFD. ${ }^{47}$ Further studies are needed. Third, changes of gut microbiota, as detected in $\mathrm{CD},{ }^{48}$ might also occur in patients with NCGS. Finally, a further aspect potentially linking NCGS with IBS is that HLA-DQ8 transgenic mice sensitised by gliadin displayed an increased secretion of acetylcholine from the myenteric plexus, enhancing muscle contractility and epithelial hypersecretion. Gluten withdrawal reversed both abnormalities. ${ }^{49}$

\section{Evidence from double-blind placebo-controlled trials}

Consistent evidence indicates the existence of an overlap between IBS and gluten-related disorders. In fact, about 5\% of patients with IBS tests positive for CD and, conversely, CD may present with typical IBS-like symptoms. ${ }^{50} 51$ Moreover, IBS-like symptoms occur in the majority of patients with NCGS, ${ }^{40}$ while about one-third of patients with IBS may have NCWPS. ${ }^{37}$ Although wheat is now established to be linked to IBS, the component(s) that actually trigger(s) symptoms remain unknown. In this line, the only way to confirm the possible role of gluten or wheat as causative factors of NCGS/NCWPS is a DBPC strategy. ${ }^{27}$ This is an expensive and time-consuming procedure and, therefore, it is not yet of routine use being confined to research setting. ${ }^{37-39} 435253$ So far, few DBPC trials have been performed. Their design and results are shown in table 1 . The findings are discordant with a variation from approximately $30 \%$ of 920 patients with IBS in a routine clinical setting being sensitive to wheat protein, of whom the majority has NCWPS associated with multiple food hypersensitivity, ${ }^{37}$ to greater symptoms induction overall with gluten or wheat protein, ${ }^{38} 3953$ to gluten-specific responses for current feelings of depression but not for abdominal symptoms. ${ }^{3853}$

Reasons for apparent heterogeneity of results require dissection. First, subject selection might be a factor. For example, contamination of the cohort with CD can unduly skew results. This is why the exclusion of CD by combined histological and serological assessment while consuming adequate gluten is so important. In this respect, a critical point is to decide whether patients carrying HLA-DQ2/DQ8 and showing increased IEL density should be excluded from DBPC. Since about $40 \%$ of patients with NCGS is HLA-DQ2/DQ8+ and shows an increased IEL density, their exclusion would represent a preselection bias. In addition, 30-90\% with positive responses to wheat protein/gluten has elevated IEL density in several studies. $^{54}$ In the study in which $30 \%$ of patients with IBS showed sensitivity to wheat, there was a high incidence of eosinophilic infiltration of the mucosa and epithelium, features not described in the other reports, suggesting a different cohort being investigated. ${ }^{37}$ Second, nocebo responses can be a problem in re-challenge arms as evident in most, but not all, cross-over studies reported above. In the Australian study, 3 of 37 patients had gluten-specific induction of symptoms, but none of those three had such specificity of responses when a further DBPC challenge was instituted. ${ }^{43}$ The Italian study had 3 of 61 patients who demonstrated unequivocal specificity of gluten-induction of symptoms. ${ }^{39}$ It would be interesting to see if this is reproducible on a further DBPC challenge. Third, the active product that was used for the challenge differed from carbohydrate-depleted wheat protein ${ }^{43} 53$ to purified gluten ${ }^{39}$ to whole wheat flour, ${ }^{37} 52$ in its dose from low ${ }^{39}$ to high, ${ }^{37} 383952$ and in its form of presentation from capsule ${ }^{37} 39$ to food. ${ }^{38} 4352$ Finally, other design features including method of assessing the end-points and sample size differed.

Based on these findings, it is reasonable to speculate that gluten and/or other wheat proteins (such as ATIs) ${ }^{30}$ can generate intestinal and extraintestinal manifestations in a subgroup of patients with IBS. This contention is supported by mechanistic studies demonstrating epithelial injury and innate and possibly adaptive immune activation in response to wheat proteins. However, gluten and wheat are not the only dietary proteins involved in IBS. Proteins derived from milk, yeast and soy maybe involved in some, ${ }^{17} 37$ and IgE-mediated food allergy and nickel allergy have been reported in a significant proportion of patients with IBS and NCGS/NCWPS. ${ }^{37} 40$

\section{THE ROLE OF FODMAPS IN IBS}

\section{The development of the FODMAP story}

Over many years, there have been multiple observations that ingestion of certain short-chain carbohydrates-lactose, fructose and sorbitol, and fructo-oligosaccharides and galactooligosaccharides-was able to induce IBS-like symptoms, and that their restriction in the diet was associated with apparent improvement in symptoms in some patients with IBS (as reviewed in detail ${ }^{22}$ ). These carbohydrates have several key features in common. They are small molecules, containing only 1-10 sugars, and hence are possible osmotically active substances in the lumen of the intestine. They are slowly absorbed in the small intestine if monosaccharides are not absorbed at all if they contain more than one sugar due to lack of suitable hydrolases. Hence, they are present in the small intestinal lumen for a prolonged time and do increase the intestinal luminal water content. Their malabsorption leads to their exposure to intestinal bacteria, which rapidly ferment them to release shortchain fatty acids and gases (hydrogen, carbon dioxide and, in some people, methane). Their effects on symptoms and gas production are also additive.

Two hypotheses were proposed: (1) the luminal distension evoked by FODMAPs was related to symptom generation; (2) in patients with IBS and its associated visceral hypersensitivity, reducing the intake of all those short-chain carbohydrates would optimally improve the symptom burden. This was different to previous dietary strategies in that only one or two species of those carbohydrates-for example, lactose in lactose malabsorbers, fructose alone or in combination with sorbitol or fructans in fructose malabsorbers-were restricted.

\section{Structure and implementation of the low FODMAP diet}

A dietary approach was designed to reduce the intake of all FODMAP groups, by finding in each food group low-FODMAP alternatives. Other adjuncts to reducing FODMAP intake, such as the use of lactase in food or orally to reduce lactose content of relevant foods, and the use of co-ingestion of glucose with food containing an excess of free fructose, were also proposed in patients with IBS. ${ }^{22}$ Knowledge of the FODMAP content of foods was patchy and limited, and an ongoing programme of detailed food analyses has corrected aberrant assumptions and filled in many gaps. ${ }^{55-57}$ Such information has been made readily available by an application (the Monash University Low FODMAP Diet App) that is updated regularly.

The diet has been implemented by education via a dietitian trained in the principles of the diet. The dietitian would tailor the dietary advice to the eating patterns of the individual, ensure nutritional adequacy and provide written information and where to find accurate digital information. After 4-6 weeks, no or minimal response in an adherent patient should then lead 
Table 1 Summary of double-blind placebo-controlled trials in non-coeliac patients with IBS symptoms and suspected gluten/wheat sensitivity

\begin{tabular}{|c|c|c|c|c|c|c|}
\hline Study design & Inclusion criteria & $\begin{array}{l}\text { Mode of administration of } \\
\text { gluten/wheat ( } \mathrm{g} / \text { day) }\end{array}$ & Placebo & Duration of the trial & Results & Reference \\
\hline Cross-over DBPC & $\begin{array}{l}\text { Non-coeliac patients ( } n=6) \text { with } \\
\text { chronic diarrhoea, abdominal pain, } \\
\text { bloating, rumbling, malaise, } \\
\text { nausea, weight loss, recurrent } \\
\text { mouth ulcerations. } \\
\text { Improvement after GFD and } \\
\text { worsening on gluten challenge. } \\
\text { Mean average GFD at DBPC time: } \\
46 \text { months }\end{array}$ & $\begin{array}{l}\text { Tomato soup supplemented with } \\
\text { sachets made up of gluten- } \\
\text { containing flour ( } 20 \mathrm{~g} / \mathrm{day})\end{array}$ & $\begin{array}{l}\text { Tomato soup } \\
\text { supplemented with } \\
\text { gluten-free flour sachets }\end{array}$ & $\begin{array}{l}4 \text { weeks with administration of } \\
\text { sachets randomly through each day } \\
\text { for the first } 3 \text { days of weeks } 2 \text { and } 4\end{array}$ & $\begin{array}{l}\text { Significant worsening of overall intestinal } \\
\text { symptoms for each patient in the week of } \\
\text { gluten-containing flour administration vs the } \\
\text { control week ( } p=0.0025 \text { ) }\end{array}$ & Cooper et $a^{52}$ \\
\hline Randomised DBPC & $\begin{array}{l}\text { Patients with IBS ( } n=34 \text { ) with } \\
\text { symptoms fulfilling Rome III } \\
\text { criteria. } \\
\text { Improvement of symptoms after } \\
\text { GFD for at least } 6 \text { weeks before } \\
\text { DBPC }\end{array}$ & $\begin{array}{l}\text { Gluten-free bread/muffin } \\
\text { supplemented with } \\
\text { carbohydrate-depleted wheat } \\
\text { protein ( } 16 \mathrm{~g} / \text { day) }\end{array}$ & $\begin{array}{l}\text { Gluten-free bread/ } \\
\text { muffin }\end{array}$ & $\begin{array}{l}6 \text { weeks with daily administration of } \\
\text { bread/muffin with or without wheat } \\
\text { protein randomly }\end{array}$ & $\begin{array}{l}\text { Significant worsening of overall symptoms } \\
\text { (abdominal pain, bloating, satisfaction in stool } \\
\text { consistency, tiredness) in patients with wheat } \\
\text { protein ingestion vs those without wheat protein } \\
\text { ingestion ( } p=0.047 \text { ) }\end{array}$ & Biesiekierski et $\left.a\right|^{53}$ \\
\hline $\begin{array}{l}\text { Cross-over, } \\
\text { randomised DBPC }\end{array}$ & $\begin{array}{l}\text { Patients with IBS ( } \mathrm{n}=276 \text { ) with } \\
\text { symptoms fulfilling Rome II } \\
\text { criteria. } \\
\text { Improvement of symptoms after } \\
\text { GFD }\end{array}$ & $\begin{array}{l}\text { Wheat flour-containing capsules } \\
\text { (13 g/day) }\end{array}$ & $\begin{array}{l}\text { Xylose-containing } \\
\text { capsules }\end{array}$ & $\begin{array}{l}5 \text { weeks with one type of capsules for } \\
2 \text { weeks, washout in the 3rd week } \\
\text { and the other type of capsules in the } \\
\text { 4th and 5th week }\end{array}$ & $\begin{array}{l}\text { Significant worsening of overall intestinal } \\
\text { symptoms in the weeks of wheat administration } \\
\text { vs the weeks without wheat ingestion } \\
(p<0.0001)\end{array}$ & Carroccio et $a l^{37}$ \\
\hline $\begin{array}{l}\text { Cross-over } \\
\text { randomised DBPC }\end{array}$ & $\begin{array}{l}\text { Patients with suspected NCGS who } \\
\text { fulfilled Rome III criteria for IBS } \\
\text { ( } n=37) \\
\text { Improvement of symptoms after } \\
\text { GFD for at least } 6 \text { weeks before } \\
\text { DBPC }\end{array}$ & $\begin{array}{l}\text { Food with high }(16 \mathrm{~g} / \text { day) or low } \\
\text { content }(2 \mathrm{~g} / \text { day) of } \\
\text { carbohydrate-depleted wheat } \\
\text { protein }\end{array}$ & $\begin{array}{l}\text { Gluten-free food with } \\
\text { whey protein ( } 16 \mathrm{~g} / \text { day) }\end{array}$ & $\begin{array}{l}\text { 2-week-run-in period with a } \\
\text { low-FODMAPs diet, then } 1 \text { week with } \\
\text { high or low-gluten diet or placebo, } \\
\text { followed by a 2-week washout before } \\
\text { crossing over to the next diet }\end{array}$ & $\begin{array}{l}\text { Significant improvement of overall intestinal } \\
\text { symptoms during reduced FODMAP diet } \\
(p<0.0001) \text { and significant but similar worsening } \\
\text { on a diet with wheat protein or placebo-3 } \\
\text { patients with wheat protein-specific response }\end{array}$ & Biesiekierski et a/ ${ }^{43}$ \\
\hline $\begin{array}{l}\text { Cross-over } \\
\text { randomised DBPC }\end{array}$ & $\begin{array}{l}\text { Patients with suspected NCGS who } \\
\text { fulfilled Rome III criteria for IBS } \\
(\mathrm{n}=22) \text { - subset of population as } \\
\text { Biesiekierski et al/ }\end{array}$ & $\begin{array}{l}\text { Food with high content of } \\
\text { carbohydrate-depleted wheat } \\
\text { protein }(16 \mathrm{~g} / \text { day })\end{array}$ & $\begin{array}{l}\text { Gluten-free food with } \\
\text { whey protein }(16 \mathrm{~g} / \text { day }) \\
\text { or placebo }\end{array}$ & $\begin{array}{l}3 \text { days with high gluten, whey protein } \\
\text { or placebo diet with } \geq 3 \text {-day washout } \\
\text { before crossing over to the next diet }\end{array}$ & $\begin{array}{l}\text { Significant but similar worsening of abdominal } \\
\text { symptoms in all dietary arms - no patient with } \\
\text { specific wheat protein-mediated response. } \\
\text { Specific increase in current feelings of depression } \\
\text { in wheat protein arm }(\mathrm{p}=0.011)\end{array}$ & $\begin{array}{l}\text { Biesiekierski et al } i_{i}^{43} \\
\text { Peters et } a l^{38}\end{array}$ \\
\hline $\begin{array}{l}\text { Cross-over } \\
\text { randomised DBPC }\end{array}$ & $\begin{array}{l}\text { Patients with suspected NCGS } \\
(\mathrm{n}=61) \text { with intestinal (IBS-like) } \\
\text { and extra-intestinal symptoms }\end{array}$ & $\begin{array}{l}\text { Capsules ( } 4.375 \mathrm{~g} / \text { day) } \\
\text { containing purified gluten }\end{array}$ & $\begin{array}{l}\text { Rice starch containing } \\
\text { capsules }\end{array}$ & $\begin{array}{l}1 \text { week with one type of capsules, } \\
1 \text { week washout before crossing over } \\
\text { to another week with the other type } \\
\text { of capsules }\end{array}$ & $\begin{array}{l}\text { Significant worsening of overall symptoms after } \\
\text { gluten ingestion vs placebo ( } p=0.034 \text { ) (bloating, } \\
p=0.040 \text {, abdominal pain, } p=0.047 \text {, foggy mind, } \\
p=0.019 \text {, depression, } p=0.020 \text {, aphthous } \\
\text { stomatitis, } p=0.025 \text { ) } \\
3 \text { patients with gluten-specific response }\end{array}$ & Di Sabatino et $a l^{39}$ \\
\hline
\end{tabular}


to the abandonment of FODMAP restriction. If there has been a good response, consideration is then given to reducing the level of restriction by graded reintroduction of previously restricted foods with a focus on specific FODMAP groups. The patient is encouraged in the long term to restrict only to the level that is needed for symptomatic comfort.

\section{Evidence to support the low FODMAP approach}

It is timely to critically review whether the FODMAP concept and the use of a low FODMAP diet in patients with IBS are supported by evidence.

\section{Mechanisms of action}

Water output from the small bowel varied by a mean of $20 \%$ between diets of moderate and low intake in ileostomates, ${ }^{58}$ and the volume of water in the small intestinal lumen as shown by MRI was markedly increased following the ingestion of mannitol, fructose or fructans compared with that following glucose. $^{59} 60$ Furthermore, the luminal distension induced by fructose was independent of whether any fructose reached the large bowel (as shown by breath hydrogen production). ${ }^{60} \quad 61$ Diets differing in FODMAP content also lead to marked differences in breath hydrogen production. ${ }^{62}$ In addition in methane producers, high FODMAP intake favoured hydrogen production while low FODMAP intake preferentially led to the production of methane, which takes up one-fifth of the volume per hydrogen atom generated than does hydrogen gas. ${ }^{62}$ Thus, there is close correlation between mechanoreceptor stimulation via small and large intestinal luminal distension and symptom genesis. Importantly, the degree of luminal distension is unlikely to differ overall between patients with IBS and healthy controls since small intestinal distension occurs similarly in both ${ }^{59}$ and breath hydrogen production does not differ when fed diets high or low in FODMAPs. ${ }^{61} 62$ The difference in symptom generation relates more to the presence of visceral hypersensitivity as shown with regard to symptom generation with lactose malabsorption. ${ }^{63}$

Unanswered questions include the mechanism by which FODMAP intake increases gastro-oesophageal reflux ${ }^{64}$ or induces tiredness. $^{62}$ The role of chemoreceptor stimulation via taste receptors or short-chain fatty acid receptors with subsequent hormonal changes warrants further exploration. Likewise, the relationship of the efficacy of the diet with specific alterations in the microbiome, immune activation, specific patterns of dysmotility and the role of changes of gut microbiota when FODMAP intake is reduced ${ }^{65}$ in ongoing efficacy have yet to be explored.

\section{Heterogeneity of physiological effects across FODMAPs}

The principle that all FODMAPs have similar physiological effects and therefore should be considered together is true only to a limited extent. While all are capable of exerting an osmotic effect, this will vary according to the molecular weight and the rapidity of absorption. Thus, fructose and polyols have a greater osmotic effect per molecule than fructans and galacto-oligosaccharides, but the number of molecules in the lumen will fall more distally with fructose and polyols associated with their slow absorption as opposed to no absorption for oligosaccharides. Nevertheless, imaging does show greater small intestinal distension with fructose and mannitol or sorbitol. ${ }^{59}$ Conversely, oligosaccharides will have greater fermentative effects as they are not absorbed as opposed to absorption of fructose and polyols across the small intestinal wall, which is likely to vary according to the dose and speed of intestinal transit, and, for fructose, the luminal glucose content (glucose facilitates fructose absorption ${ }^{22}$ ) and individual absorptive capacity via fructose-specific transporters. While all FODMAPs are readily fermented, the relative speeds of fermentation of individual FODMAP groups have not been specifically studied. Each FODMAP group may have different effects on the structure and function of microbiota, but this has not been systematically assessed. In clinical practice, patients report different sensitivities to FODMAP groups, but such observations have not been formally studied.

\section{Efficacy of the low FODMAP diet}

Seven studies with a variety of designs examining the efficacy of the low FODMAP diet have been published, and these are outlined in table $2 .{ }^{62}$ 66-72 The studies uniformly show efficacy in around $70 \%$ of patients with IBS of any bowel habit type. The limitations of the evidence presented above include the choice of placebo (such as habitual diet), the short-term nature of the studies ( 3 days to 6 weeks), the lack of blinding in many and questions about the success of blinding in others. ${ }^{73}{ }^{74}$ Such issues are endemic in dietary intervention studies often without ready solutions as reviewed by Yao et al. ${ }^{75}$ However, the consistency of findings is somewhat reassuring, and durability of the benefits has been supported by an observational study with a median duration over 12 months. $^{72}$

\section{Implementation of the low FODMAP diet}

The low FODMAP diet restricts all FODMAP groups in its induction phase, followed by a step-down in restriction after 4-6 weeks if efficacious, but each aspect of this plan has not been subject to specific study. First, the need to restrict across all FODMAP groups should theoretically be associated with the highest chance of response, but this has not been tested. In observational studies, poorly defined diets that restricted fructose \pm sorbitol claimed benefits in $40-81 \%$ of patients with IBS or functional bloating. ${ }^{76-78}$ Similarly, a diet that restricted fructose and fructans in 62 patients with IBS and fructose malabsorption reported benefit in 74\%; step-up to other FODMAPs was only used if response was poor. ${ }^{79}$ Second, while controlled trials have shown that maximal response in symptom reduction occurs within 7 days when all food is provided and a high degree of adherence is achieved, there is no evidence-base behind a 4-6 week induction. This duration was proposed give the patient time to learn the diet and to ensure persistence of the symptomatic improvement. It also offers a practical timeframe for review.

\section{Adherence and degree of difficulty in following the diet}

Adherence was high where all food was provided on the basis of dietary diaries and breath hydrogen testing. ${ }^{67}$ However, where the diet is taught in a clinical setting, the ease to which patients can apply the diet and the consequent adherence are important issues. In a prospective evaluation of 90 patients with IBS in New Zealand, in which the diet was taught by a dietitian via one or two consultations, $61 \%$ of participants stated that the diet was easy to follow and $44 \%$ were able to incorporate the diet easily into their life. ${ }^{72}$ Adherence rates were also high, possibly because non-adherence was associated with symptom induction.

\section{Risks of a diet low in FODMAPs}

Broad dietary change is associated with several risks that might include the following. First, nutritional adequacy of the low FODMAP diet has been evaluated in one study, where dietary 
Table 2 Summary of clinical trials evaluating efficacy of the low FODMAP diet in patients with IBS

\begin{tabular}{|c|c|c|c|c|c|c|}
\hline Study design & $\begin{array}{l}\text { Inclusion } \\
\text { criteria }\end{array}$ & Low FODMAP & Comparator & $\begin{array}{l}\text { Duration of the } \\
\text { trial }\end{array}$ & Results & Reference \\
\hline $\begin{array}{l}\text { Single-blind, } \\
\text { randomised } \\
\text { cross-over }\end{array}$ & $\begin{array}{l}\text { Healthy subjects } \\
(n=15) \text { and } \\
\text { patients with } \\
\text { IBS }(n=15)\end{array}$ & $\begin{array}{l}\text { All food provided with } \\
\text { low FODMAP content } \\
(9 \mathrm{~g} / \text { day })\end{array}$ & $\begin{array}{l}\text { All food provided with } \\
\text { high FODMAP content } \\
\text { ( } 50 \mathrm{~g} / \text { day) }\end{array}$ & $\begin{array}{l}2 \text { days of } \\
\text { interventions with } \\
\text { 7-day washout }\end{array}$ & $\begin{array}{l}\text { Abdominal symptoms and } \\
\text { lethargy greater with the high } \\
\text { FODMAP diet in IBS }(p=0.002) \text {. } \\
\text { Only increased flatus production } \\
\text { in health controls }\end{array}$ & Ong et $a f^{62}$ \\
\hline $\begin{array}{l}\text { Non-randomised } \\
\text { comparative }\end{array}$ & $\begin{array}{l}\text { Patients with } \\
\text { IBS }(n=72)\end{array}$ & $\begin{array}{l}\text { Dietitian-taught low } \\
\text { FODMAP diet }\end{array}$ & $\begin{array}{l}\text { Dietitian-taught standard } \\
\text { diet }\end{array}$ & $\begin{array}{l}\text { Assessed by } \\
\text { questionnaire at } \\
\text { follow-up dietetic } \\
\text { appointment }\end{array}$ & $\begin{array}{l}\text { Satisfaction with IBS symptoms } \\
76 \% \text { with low FODMAP diet vs } \\
54 \% \text { with standard diet; } \\
\text { composite symptom score } 86 \% \text { vs } \\
49 \% \text { ( } p<0.001) \text {; improvements in } \\
\text { bloating } 82 \% \text { vs } 49 \%(p=0.002) \text {, } \\
\text { abdominal pain } 85 \% \text { vs } 61 \% \\
(p=0.023) \text {; flatulence } 87 \% \text { vs } \\
50 \%(p=0.001) \text {. }\end{array}$ & $\begin{array}{l}\text { Staudacher } \\
\text { et } a l^{68}\end{array}$ \\
\hline $\begin{array}{l}\text { Single-blind } \\
\text { randomised }\end{array}$ & $\begin{array}{l}\text { Patients with } \\
\text { IBS }\end{array}$ & $\begin{array}{l}\text { Dietitian-taught low } \\
\text { FODMAP diet }(n=19)\end{array}$ & Habitual diet $(n=22)$ & 4 weeks & $\begin{array}{l}\text { Adequate control of symptoms } \\
68 \% \text { of } 19 \text { for low FODMAP diet } \\
\text { vs } 23 \% \text { of } 22 \text { with habitual diet } \\
(p=0.005)\end{array}$ & $\begin{array}{l}\text { Staudacher } \\
\text { et } a l^{69}\end{array}$ \\
\hline $\begin{array}{l}\text { Prospective } \\
\text { observational }\end{array}$ & $\begin{array}{l}\text { Patients with } \\
\text { IBS }(n=90)\end{array}$ & $\begin{array}{l}\text { Dietitian-taught low } \\
\text { FODMAP diet }\end{array}$ & Nil & Mean 15.7 months & $\begin{array}{l}72 \% \text { satisfied with symptom } \\
\text { response via questionnaire; } 76 \% \\
\text { adherent to the diet }\end{array}$ & $\begin{array}{l}\text { De Roest } \\
\text { et } a l^{72}\end{array}$ \\
\hline $\begin{array}{l}\text { Single-blind, } \\
\text { randomised } \\
\text { cross-over }\end{array}$ & $\begin{array}{l}\text { Patients with } \\
\text { IBS who fulfilled } \\
\text { Rome III criteria } \\
\text { for IBS }(n=30) \text {. } \\
\text { Healthy controls } \\
(n=8)\end{array}$ & $\begin{array}{l}\text { All food provided with } \\
\text { low FODMAP content }\end{array}$ & $\begin{array}{l}\text { All food provided with } \\
\text { FODMAP content similar } \\
\text { to estimated content of a } \\
\text { typical Australian diet }\end{array}$ & $\begin{array}{l}3 \text { weeks for each } \\
\text { dietary intervention } \\
\text { with at least } 3 \text { weeks } \\
\text { washout between }\end{array}$ & $\begin{array}{l}\text { For the low FODMAP diet } \\
\text { Lower abdominal symptoms } \\
\text { than typical FODMAP diet } \\
(p<0.001) \\
\text { Improved symptoms compared } \\
\text { with habitual diet during } \\
\text { run-in }(\mathrm{p}<0.001) \\
70 \% \text { showed clinically } \\
\text { significantly improvement }\end{array}$ & $\begin{array}{l}\text { Halmos } \\
\text { et } a l^{67}\end{array}$ \\
\hline $\begin{array}{l}\text { Consecutive } \\
\text { prospective } \\
\text { observational }\end{array}$ & $\begin{array}{l}\text { Patients with } \\
\text { IBS (Rome III; } \\
n=19 \text { ) }\end{array}$ & $\begin{array}{l}\text { e-health-delivered low } \\
\text { FODMAP diet }\end{array}$ & Habitual diet & $\begin{array}{l}6 \text { weeks habitual diet } \\
\text { followed by } 6 \text { weeks } \\
\text { low FODMAP diet }\end{array}$ & $\begin{array}{l}\text { Improvement in symptoms and } \\
\text { quality of life with low FODMAP } \\
\text { diet }\end{array}$ & $\begin{array}{l}\text { Pederson } \\
\text { et } a l^{70}\end{array}$ \\
\hline $\begin{array}{l}\text { Non-blinded } \\
\text { randomised } \\
\text { placebo-controlled }\end{array}$ & $\begin{array}{l}\text { Patients with } \\
\text { IBS (Rome III) }\end{array}$ & $\begin{array}{l}\text { e-health-delivered low } \\
\text { FODMAP diet }(n=42)\end{array}$ & $\begin{array}{l}\text { Probiotic+habitual diet } \\
(n=41) ; \text { and habitual } \\
\text { diet alone }(n=40)\end{array}$ & 6 weeks & $\begin{array}{l}\text { Low FODMAP diet superior to } \\
\text { placebo }(p<0.01) \text {, but not to } \\
\text { probiotic }(p=0.20) \text {; probiotic not } \\
\text { superior to placebo }(p=0.13)\end{array}$ & $\begin{array}{l}\text { Pederson } \\
\text { et } a l^{71}\end{array}$ \\
\hline
\end{tabular}

calcium intake was compromised in some patients, presumably those who restricted lactose. The low FODMAP diet can be associated with reduction of fibre intake unless action is taken to seek non-wheat sources of fibre, as is instructed by dietitians delivering the diet. The nutritional adequacy of the low FODMAP diet needs to be assessed in a larger population, particularly in those who are self-taught. Second, the psychosocial risks of imposing dietary change cannot be underplayed. These range from difficulties in socialisation and eating away from home through to the precipitation of eating disorders such as orthorexia nervosa. ${ }^{80}$ Third, the physiological effects of reducing FODMAP intake beyond those targeted to improve symptoms may have other implications. The major effect documented to date is alteration by varying FODMAP intake of gut microbiota, such as changing total bacteria abundance and altering the relative abundance of Bifidobacteria. ${ }^{69}$ Diets differing in their FODMAP content were also associated with changes in the relative abundance of strongly butyrateproducing Clostridal groups or the mucus-associated bacterium Akkermansia muciniphila, both of which are positively associated with health. ${ }^{65}$ Interestingly, the changes in these bacteria comprised increased relative abundance in association with greater FODMAP intake than with the low FODMAP diet arm per se in comparison to the habitual diet. The health implications of such changes are not known but raise concerns about strict restriction of FODMAPs in the long term.

\section{DIETARY THERAPY IN IBS AND PERCEIVED WHEAT SENSITIVITY}

Patients appear to be increasingly recognising an association of induction of gut symptoms and/or fatigue with the ingestion of wheat products such as bread and pasta. An Australian survey of 1184 adults identified that $8 \%$ avoid wheat or are gluten-free to relieve such symptoms. ${ }^{25}$ Because of the coexistence of fructans and gluten in wheat, ${ }^{57}$ the dilemma from a clinical point of view is which of the two evidence-based dietary approachesGFD or low FODMAP diet-does one advise after excluding coeliac disease. A low FODMAP diet may offer a higher chance of symptomatic response, but GFD involves attacking a specific pathogenic factor if the injurious nature of wheat protein is integral to the genesis of visceral hypersensitivity or other gut-related physiological changes. In the absence of a biomarker of NCWPS, the only available means of identifying specific sensitivity to wheat protein is a trial of exclusion diet (strict GFD) and then DBPC re-challenge using purified wheat protein or gluten with symptoms as the read-out, as discussed earlier.

There is no consensus regarding the choice of approach. Comparisons between the two dietary approaches are shown in 
Table 3 Comparison of gluten-free and low-FODMAP diets in patients with IBS with apparent wheat intolerance

\begin{tabular}{|c|c|c|}
\hline & Gluten-free diet & Low FODMAP diet \\
\hline $\begin{array}{l}\text { Putative pathogenic } \\
\text { mechanisms targeted }\end{array}$ & $\begin{array}{l}\text { Epithelial injury, alteration of intestinal permeability } \\
\text { Stimulation of innate immune mechanisms }\end{array}$ & Mechanoreceptor stimulation via luminal distension in small and large intestine \\
\hline Likelihood of efficacy & $24 \%$ of 920 patients with IBS 36 & Efficacy in $68-76 \%^{22}$ \\
\hline Time for response & Not reported & Within 7 days ${ }^{65}$ \\
\hline Predictors of response & $\begin{array}{l}\text { Increase intraepithelial density in duodenum } \\
\text { Positive double-blind placebo-controlled re-challenge or } \\
\text { confocal laser endomicrosopic lesions in response to } \\
\text { exposure } 17 \\
\text { Latent coeliac disease }\end{array}$ & Nil reported \\
\hline Durability of response & Durable over 1 year $(n=13)^{17}$ & $72 \%(n=90)$ satisfied with mean follow-up 15.7 months $^{72}$ \\
\hline Ease of introduction & $\begin{array}{l}\text { Large amount of high-quality literature available on the } \\
\text { GFD } \\
\text { Dietitians trained in GFD widely in some but not other } \\
\text { countries } \\
\text { No information regarding patients' perspective }\end{array}$ & $\begin{array}{l}\text { High quality information readily available } \\
\text { Paucity of dietitians trained in this diet in many countries } \\
61 \% \text { patients find it easy to follow, } 44 \% \text { easily incorporated into lifestyle in } \\
\text { prospective study }(n=90)^{72}\end{array}$ \\
\hline Adherence & Not reported in this patient group & Adherence $76 \%$ in prospective $(n=90)$ observational study ${ }^{72}$ \\
\hline Advantages & $\begin{array}{l}\text { Diet directed to underlying pathogenic mechanism } \\
\text { Widely understood and packaged/processed foods available } \\
\text { in many countries } \\
\text { - Restriction only in one food group }\end{array}$ & $\begin{array}{l}\text { High chance of response } \\
\text { In the long term, need only reduce the level of FODMAP intake sufficiently } \\
\text { to achieve symptomatic benefit. Alternatives available across all four food } \\
\text { groups }\end{array}$ \\
\hline Disadvantages & $\begin{array}{l}\text { Low chance of symptomatic response } \\
\text { - Gluten-free packaged/processed food: } \\
\text { - More expensive } \\
\text { - Often high fat, high sugar } \\
\text { - Issues of food texture (breads, pasta, cakes, biscuits) } \\
\text { Exclusion diet=requirement for total abstinence from gluten } \\
\text { Difficult in countries where food labelling inadequate }\end{array}$ & $\begin{array}{l}\text { Symptomatic therapy only } \\
\text { Restrictions across a four food groups } \\
\text { International food database of FODMAP content limited } \\
\text { Limited availability of branded low FODMAP packaged and/or processed } \\
\text { foods }\end{array}$ \\
\hline $\begin{array}{l}\text { Specific risks: nutritional } \\
\text { adequacy }\end{array}$ & $\begin{array}{l}\text { Restrictions on the intake of many breads and cereals may } \\
\text { lead to deficient intake of folate, thiamine, fibre } \\
\text { Calcium, iron and zinc intake less than population } \\
\text { - Many gluten-free foods not nutritionally balanced }\end{array}$ & $\begin{array}{l}\text { If not exchanged for low FODMAP alternatives: } \\
\text { - Restriction of lactose-containing dairy products may lead to deficient } \\
\text { intake of calcium, vitamin D } \\
\text { - Restriction of legumes, grains and cereals may lead to deficient intake of } \\
\text { folate, thiamine, fibre } \\
\text { - Natural prebiotic intake reduced }{ }^{65}\end{array}$ \\
\hline Specific risks: other & $\begin{array}{l}\text { Risks of precipitating an eating disorder } \\
\text { Impaired ability to exclude coeliac disease if diet } \\
\text { commenced prior to investigation }\end{array}$ & $\begin{array}{l}\text { Risks of precipitating an eating disorder } \\
\text { Alteration of gut microbiota when on strict FODMAP restriction }{ }^{67} \text { has } \\
\text { unknown implications for long term }\end{array}$ \\
\hline
\end{tabular}

table 3. The GFD approach might be preferable if the clinic is geared towards exclusion diet followed by DBPC re-challenge. Those having a negative response could have a trial with low FODMAP diet. Alternatively, the re-challenge methodology might be better applied in those with biomarkers suggesting relevant pathogenic events occurring in the intestine. Increased duodenal IEL density ( $>25 / 100$ enterocytes), raised faecal eosinophilic cationic protein and tryptase, ${ }^{81}$ basophil activation in vitro $^{18}$ or circulating antibodies to whole gliadin might enable better targeting of wheat protein challenges. ${ }^{37} \mathrm{~A}$ third alternative is that the low FODMAP diet is applied initially and, in those with insufficient response, gluten is also removed from the diet. If an adequate response occurs, then non-wheat-based FODMAP intake can be cautiously increased in a step-wise fashion to determine whether that is necessary.

\section{FUTURE PERSPECTIVES}

Much of the controversy has been generated by the poor awareness of the potential components of wheat that can induce symptoms. Gluten has been assumed to be the culprit because of its unequivocal key role in the pathogenesis of coeliac disease. In this way, the use of 'gluten' should be restricted to situations where gluten is the documented inducer of symptoms, 'wheat protein' where that has been the challenged factor, and 'wheat' where wheat products, such as bread, are used as the challenging agent. Likewise, further consideration will be needed in the terminology of clinical syndromes so that the current confusion of NCGS, NCWS and NCWPS can be put to rest. The lack of biomarkers for food protein sensitivity per se or individual protein sources is a significant impediment to progress. There has been considerable advancement in the application of techniques, such as confocal endomicrosocopy, ${ }^{17}$ which holds promise as gold standards upon which practical biomarkers might be compared.

For interventional studies, exclusion of CD is critical and non-gluten-dependent diagnostic tests such as detection of gluten-reactive T-cells ex vivo ${ }^{82}$ are needed. Likewise, the design of such studies may benefit from expert consensus about several of the details to reduce heterogeneity and to improve the interpretation of outcomes. Long-term outcomes are also needed to reassure the durability of efficacy with various dietary strategies.

One missing aspect is whether the intestinal responses to the dietary proteins are actually translated into altered gut physiology such as visceral hypersensitivity or abnormal motility responses. If that can be proven, then it places even greater importance of defining methods of detecting such sensitivities accurately so that the underlying condition can potentially be cured rather than just symptomatically treated.

\section{CONCLUSIONS}

There has been considerable progress in the understanding of how dietary change might influence patient outcomes in IBS. 
The often heated arguments and controversies over the involvement of wheat and its components in inducing symptoms have led to a now productive and healthy state of enquiry, with several research groups pursuing an understanding of how proteins and carbohydrates can contribute to IBS symptoms. Considerable more research is needed, but the learnings are informing future research into other, non-wheat dietary proteins and into bioactive chemicals, for which there is growing interest. The place of diet, whether it be low FODMAP diet, GFD or other fancy diets, is now established in the therapeutic strategies that clinicians can offer their patients. While the truth remains clouded, facts are emerging from the fiction.

Acknowledgements The authors wish to thank Dr Giacomo Caio, Department of Medical and Surgical Sciences, University of Bologna, for insightful comments to the manuscript and valuable technical skill.

Contributors All authors contributed equally to the conceptualisation, writing and editing of this manuscript.

Competing interests PRG has published an information/recipe book on the low FODMAP diet, and his University and Department receive royalties from the sale of the Monash University low FODMAP Diet App.

Provenance and peer review Commissioned; externally peer reviewed.

\section{REFERENCES}

1 Longstreth GF, Thompson WG, Chey WD, et al. Functional bowel disorders. Gastroenterology 2006;130:1480-91.

2 Drossman DA. The functional gastrointestinal disorders and the Rome III process. Gastroenterology 2006;130:1377-90.

3 Hungin AP, Whorwell PJ, Tack J, et al. The prevalence, patterns and impact of irritable bowel syndrome: an international survey of 40,000 subjects. Aliment Pharmacol Ther 2003;17:643-50.

4 Quigley EM, Abdel-Hamid H, Barbara G, et al. A global perspective on irritable bowel syndrome: a consensus statement of the World Gastroenterology Organisation Summit Task Force on irritable bowel syndrome. J Clin Gastroenterol 2012;46:356-66.

5 Camilleri M. Peripheral mechanisms in irritable bowel syndrome. N Engl I Med 2012;367:1626-35.

6 Canavan C, West J, Card T. The epidemiology of irritable bowel syndrome. Clin Epidemiol 2014;6:71-80.

7 Barbara G, Cremon C, Carini G, et al. The immune system in irritable bowel syndrome. J Neurogastroenterol Motil 2011;17:349-59.

8 Camilleri M, Lasch K, Zhou W. Irritable bowel syndrome: methods, mechanisms, and pathophysiology. The confluence of increased permeability, inflammation, and pain in irritable bowel syndrome. Am J Physiol Gastrointest Liver Physiol 2012;303: G775-85.

9 Thomas A, Quigley EM. Diet and irritable bowel syndrome. Curr Opin Gastroenterol 2015:31:166-71.

10 Simrén $\mathrm{M}$, Månsson A, Langkilde AM, et al. Food-related gastrointestinal symptoms in the irritable bowel syndrome. Digestion 2001;63:108-15.

11 Gibson PR. Food intolerance in functional bowel disorders. I Gastroenterol Hepatol 2011;26(Suppl 3):128-31.

12 Barbara G, Stanghellini V, De Giorgio R, et al. Activated mast cells in proximity to colonic nerves correlate with abdominal pain in irritable bowel syndrome. Gastroenterology 2004;126:693-702.

13 Barbara G, Wang B, Stanghellini V, et al. Mast cell-dependent excitation of visceral-nociceptive sensory neurons in irritable bowel syndrome. Gastroenterology 2007;132:26-37

14 Zhao $\mathrm{P}$, Lieu T, Barlow N, et al. Cathepsin $\mathrm{S}$ causes inflammatory pain via biased agonism of PAR2 and TRPV4. J Biol Chem 2014;289:27215-34.

15 Sampson HA, Albergo R. Comparison of results of skin tests, RAST, and double-blind, placebo-controlled food challenges in children with atopic dermatitis. J Allergy Clin Immunol 1984;74:26-33.

16 Bischoff SC, Mayer J, Wedemeyer J, et al. Colonoscopic allergen provocation (COLAP): a new diagnostic approach for gastrointestinal food allergy. Gut 1997:40:745-53.

17 Fritscher-Ravens A, Schuppan D, Ellrichmann M, et al. Confocal endomicroscopy shows food-associated changes in the intestinal mucosa of patients with irritable bowel syndrome. Gastroenterology 2014;147:1012-20.

18 Carroccio A, Brusca I, Mansueto P, et al. A cytologic assay for diagnosis of food hypersensitivity in patients with irritable bowel syndrome. Clin Gastroenterol Hepatol 2010;8:254-60.
19 Bucci C, Zingone F, Russo I, et al. Gliadin does not induce mucosal inflammation or basophil activation in patients with nonceliac gluten sensitivity. Clin Gastroenterol Hepatol 2013;11:1294-9.

20 Gibson PR, Shepherd SJ. Evidence-based dietary management of functional gastrointestinal symptoms: the FODMAP approach. I Gastroenterol Hepatol 2010:25:252-8.

21 Shepherd SJ, Lomer MC, Gibson PR. Short-chain carbohydrates and functional gastrointestinal disorders. Am J Gastroenterol 2013;108:707-17.

22 Tuck CJ, Muir JG, Barrett JS, et al. Fermentable oligosaccharides, disaccharides, monosaccharides and polyols: role in irritable bowel syndrome. Expert Rev Gastroenterol Hepatol 2014;8:819-34.

23 Gibson PR, Shepherd SJ. Food choice as key management strategy for functional gastrointestinal symptoms. Am J Gastroenterol 2012;107:657-66.

24 Cuomo R, Andreozzi P, Zito FP, et al. Irritable bowel syndrome and food interaction. World I Gastroenterol 2014;20:8837-45.

25 Golley S, Corsini N, Topping D, et al. Motivations for avoiding wheat consumption in Australia: results from a population survey. Public Health Nutr 2015;18:490-9.

26 Gibson PR, Muir JG, Newnham ED. Other dietary counfounders; FODMAPs et al. Dig Dis 2015;33:269-76.

27 Volta U, De Giorgio R. New understanding of gluten sensitivity. Nat Rev Gastroenterol Hepatol 2012;9.295-9.

28 Wahnschaffe U, Ullrich R, Riecken EO, et al. Celiac disease-like abnormalities in a subgroup of patients with irritable bowel syndrome. Gastroenterology 2001;121:1329-38

29 Catassi C, Bai JC, Bonaz B, et al. Non-Celiac Gluten sensitivity: the new frontier of gluten related disorders. Nutrients 2013;26;5:3839-53.

30 Junker Y, Zeissig S, Kim SJ, et al. Wheat amylase trypsin inhibitors drive intestinal inflammation via activation of toll-like receptor 4. J Exp Med 2012;209:2395-408.

31 de Punder K, Pruimboom L. The dietary intake of wheat and other cereal grains and their role in inflammation. Nutrients 2013;5:771-87.

32 Biesiekierski JR, Newnham ED, Shepherd SJ, et al. Characterization of Adults With a Self-Diagnosis of Nonceliac Gluten Sensitivity. Nutr Clin Pract 2014;29:504-9.

33 Aziz I, Lewis NR, Hadjivassiliou M, et al. A UK study assessing the population prevalence of self-reported gluten sensitivity and referral characteristics to secondary care. Eur J Gastroenterol Hepatol 2014;26:33-9.

34 Suarez FL, Savaiano DA, Levitt MD. A comparison of symptoms after the consumption of milk or lactose-hydrolyzed milk by people with self-reported severe lactose intolerance. N Engl J Med 1995;333:1-4.

35 Brown AC. Gluten sensitivity: problems of an emerging condition separate from celiac disease. Expert Rev Gastroenterol Hepatol 2012;6:43-55.

36 Di Sabatino A, Corazza GR. Nonceliac gluten sensitivity: sense or sensibility? Ann Intern Med 2012;156:309-11.

37 Carroccio A, Mansueto $P$, lacono $G$, et al. Non-celiac wheat sensitivity diagnosed by double-blind placebo-controlled challenge: exploring a new clinical entity. Am J Gastroenterol 2012;107:1898-906.

38 Peters SL, Biesiekierski JR, Yelland GW, et al. Randomised clinical trial: gluten may cause depression in subjects with non-coeliac gluten sensitivity—an exploratory clinical study. Aliment Pharmacol Ther 2014;39:1104-12.

39 Di Sabatino A, Volta U, Salvatore C, et al. Low gluten doses in patients suspected for nonceliac gluten sensitivity: a randomized, placebo-controlled, cross-over trial. Clin Gastroenterol Hepatol 2015, in press. doi:10.1016

40 Volta U, Bardella MT, Calabrò A, et al. An Italian prospective multicenter survey on patients suspected of having non-celiac gluten sensitivity. BMC Med 2014;12:85.

41 DiGiacomo DV, Tennyson CA, Green PH, et al. Prevalence of gluten-free diet adherence among individuals without celiac disease in the USA: results from the Continuous National Health and Nutrition Examination Survey 2009-2010. Scand I Gastroenterol 2013:48:921-5.

42 Sapone A, Bai JC, Ciacci C, et al. Spectrum of gluten-related disorders: consensus on new nomenclature and classification. BMC Med 2012;10:13.

43 Biesiekierski JR, Peters SL, Newnham ED, et al. No effects of gluten in patients with self-reported non-celiac gluten sensitivity after dietary reduction of fermentable, poorly absorbed, short-chain carbohydrates. Gastroenterology 2013;145:320-8

44 Sapone A, Lammers KM, Casolaro V, et al. Divergence of gut permeability and mucosal immune gene expression in two gluten-associated conditions: celiac disease and gluten sensitivity. BMC Med 2011;9:23.

45 Brottveit M, Beitnes AC, Tollefsen S, et al. Mucosal cytokine response after short-term gluten challenge in celiac disease and non-celiac gluten sensitivity. Am J Gastroenterol 2013;108:842-50.

46 Volta U, Tovoli F, Cicola R, et al. Serological tests in gluten sensitivity (nonceliac gluten intolerance). J Clin Gastroenterol 2012;46:680-5.

47 Vazquez-Roque MI, Camilleri M, Smyrk T, et al. A controlled trial of gluten-free diet in patients with irritable bowel syndrome-diarrhea: effects on bowel frequency and intestinal function. Gastroenterology 2013;144:903-11.

48 Pozo-Rubio T, Olivares M, Nova E, et al. Immune development and intestinal microbiota in celiac disease. Clin Dev Immunol 2012;2012:654143.

49 Natividad JM, Huang X, Slack E, et al. Host responses to intestinal microbial antigens in gluten-sensitive mice. PLOS ONE 2009;4:e6472. 
50 Sanders DS, Carter MJ, Hurlstone DP, et al. Association of adult coeliac disease with irritable bowel syndrome: a case-control study in patients fulfilling ROME II criteria referred to secondary care. Lancet 2001;358:1504-8.

51 O'Leary C, Wieneke P, Buckley $S$, et al. Celiac disease and irritable bowel-type symptoms. Am J Gastroenterol 2002;97:1463-7.

52 Cooper BT, Holmes GK, Ferguson R, et al. Gluten-sensitive diarrhea without evidence of celiac disease. Gastroenterology 1980;79:801-6.

53 Biesiekierski JR, Newnham ED, Irving PM, et al. Gluten causes gastrointestinal symptoms in subjects without celiac disease: a double-blind randomized placebo-controlled trial. Am J Gastroenterol 2011;106:508-14.

54 Gibson PR, Varney J, Malakar S, et al. Food components and irritable bowel syndrome. Gastroenterology 2015;148:1158-74.e4.

55 Muir JG, Shepherd SJ, Rosella O, et al. Fructan and free fructose content of common Australian vegetables and fruit. J Agric Food Chem 2007;55:6619-27.

56 Muir JG, Rose R, Rosella 0, et al. Measurement of short-chain carbohydrates in common Australian vegetables and fruits by high-performance liquid chromatography (HPLC). J Agric Food Chem 2009;57:554-65.

57 Biesiekierski JR, Rosella 0, Rose R, et al. Quantification of fructans, galacto-oligosacharides and other short-chain carbohydrates in processed grains and cereals. J Hum Nutr Diet 2011;24:154-76.

58 Barrett JS, Gearry RB, Muir JG, et al. Dietary poorly absorbed, short-chain carbohydrates increase delivery of water and fermentable substrates to the proximal colon. Aliment Pharmacol Ther 2010;31:874-82.

59 Marciani L, Cox EF, Hoad CL, et al. Postprandial changes in small bowel water content in healthy subjects and patients with irritable bowel syndrome. Gastroenterology 2010;138:469-77.

60 Murray K, Wilkinson-Smith V, Hoad C, et al. Differential effects of FODMAPs (fermentable oligo-, di-, mono-saccharides and polyols) on small and large intestinal contents in healthy subjects shown by MRI. Am J Gastroenterol 2014;109:110-19.

61 Yao CK, Tan HL, van Langenberg DR, et al. Dietary sorbitol and mannitol: food content and distinct absorption patterns between healthy individuals and patients with irritable bowel syndrome. J Hum Nutr Diet 2014;27(Suppl 2):263-75.

62 Ong DK, Mitchell SB, Barrett JS, et al. Manipulation of dietary short chain carbohydrates alters the pattern of gas production and genesis of symptoms in irritable bowel syndrome. J Gastroenterol Hepatol 2010;25:1366-73.

63 Zhu $Y$, Zheng $X$, Cong $Y$, et al. Bloating and distention in irritable bowel syndrome: the role of gas production and visceral sensation after lactose ingestion in a population with lactase deficiency. Am J Gastroenterol 2013;108:1516-25.

64 Piche T, des Varannes SB, Sacher-Huvelin S, et al. Colonic fermentation influences lower esophageal sphincter function in gastroesophageal reflux disease. Gastroenterology 2003;124:894-902.

65 Halmos EP, Christophersen CT, Bird AR, et al. Diets that differ in their FODMAP content alter the colonic luminal microenvironment. Gut 2015;64:93-100.

66 Barrett JS, Gibson PR. Development and validation of a comprehensive semi-quantitative food frequency questionnaire that includes FODMAP intake, glycemic index and glycemic load. J Am Diet Ass 2010;110:1469-76.
67 Halmos EP, Power VA, Shepherd SJ, et al. A diet low in FODMAPs reduces symptoms of irritable bowel syndrome. Gastroenterology 2014;146:67-75.

68 Staudacher HM, Whelan K, Irving PM, et al. Comparison of symptom response following advice for a diet low in fermentable carbohydrates (FODMAPs) versus standard dietary advice in patients with irritable bowel syndrome. J Hum Nutr Diet 2011;24:487-95.

69 Staudacher HM, Lomer MC, Anderson JL, et al. Fermentable carbohydrate restriction reduces luminal bifidobacteria and gastrointestinal symptoms in patients with irritable bowel syndrome. J Nutr 2012;142:1510-18.

70 Pedersen N, Vegh Z, Burisch J, et al. Ehealth monitoring in irritable bowel syndrome patients treated with low fermentable oligo-, di-, mono-saccharides and polyols diet. World J Gastroenterol 2014;20:6680-4.

71 Pedersen N, Andersen NN, Vegh Z, et al. Ehealth: Low FODMAP diet vs Lactobacillus rhamnosus GG in irritable bowel syndrome. World J Gastroenterol 2014;20:16215-26.

72 de Roest RH, Dobbs BR, Chapman BA, et al. The low FODMAP diet improves gastrointestinal symptoms in patients with irritable bowel syndrome: a prospective study. Int J Clin Pract 2013;67:895-903.

73 Camilleri M, Acosta A. Re: Halmos et al., A diet low in FODMAPs reduces symptoms of irritable bowel syndrome. Gastroenterology 2014;146:1829-30.

74 Halmos EP, Muir JG, Gibson PR. Reply: to PMID 24076059. Gastroenterology 2014;146:1830-1.

75 Yao CK, Gibson PR, Shepherd SJ. Design of clinical trials evaluating dietary interventions in patients with functional gastrointestinal disorders. Am J Gastroenterol 2013;108:748-58.

76 Fernández-Bañares F, Rosinach M, Esteve M, et al. Sugar malabsorption in functional abdominal bloating: a pilot study on the long-term effect of dietary treatment. Clin Nutr 2006:25:824-31.

77 Ledochowski M, Widner B, Bair H, et al. Fructose- and sorbitol-reduced diet improves mood and gastrointestinal disturbances in fructose malabsorbers. Scand J Gastroenterol 2000;35:1048-52.

78 Goldstein R, Braverman D, Stankiewicz H. Carbohydrate malabsorption and the effect of dietary restriction on symptoms of irritable bowel syndrome and functional bowel complaints. Isr Med Assoc J 2000;2:583-7.

79 Shepherd SJ, Gibson PR. Fructose malabsorption and symptoms of irritable bowel syndrome: guidelines for effective dietary management. J Am Diet Assoc 2006;106:1631-9.

80 Koven NS, Abry AW. The clinical basis of orthorexia nervosa: emerging perspectives. Neuropsychiatr Dis Treat 2015;11:385-94.

81 Carroccio A, Brusca I, Mansueto P, et al. Fecal assays detect hypersensitivity to cow's milk protein and gluten in adults with irritable bowel syndrome. Clin Gastroenterol Hepatol 2011;9:965-71.

82 Ontiveros N, Tye-Din JA, Hardy MY, et al. Ex-vivo whole blood secretion of interferon (IFN)- $\gamma$ and IFN- $\gamma$-inducible protein-10 measured by enzyme-linked immunosorbent assay are as sensitive as IFN- $\gamma$ enzyme-linked immunospot for the detection of gluten-reactive T cells in human leucocyte antigen (HLA)-DQ2.5(+) -associated coeliac disease. Clin Exp Immunol 2014;175:305-15. 